keep hill herbage in a more palatable and nutritionally superior state for sheep, as well as supplying weaned calves to arable farms. There are several ways to more and better lambs, but land improvement offers the greatest scope. It raises the nutritional level. Flock productivity is determined by all-the-year-round availability of green herbage, especially scarce on hills in late winter and early spring, often called the hungry gap.
Though large areas of hill-land cannot be improved economically, nevertheless about 10 per cent or $1,000,000$ acres could be improved to-day with profit to the farmer. Part can be by ploughing and re-seeding and part by surface treatment. In most districts there are progressive farmers demonstrating what can be done, but they have too few imitators. Scotland needs a new wave of enthusiasm for land reclamation.

\title{
OBITUARIES
}

\section{Sir Charles Darwin, K.B.E., F.R.S.}

Srr Charras Darwin, the distinguished mathematical physicist and former director of the National Physical Laboratory, died at Cambridge on December 31, at the age of seventy-five. He was a son of Sir George Darwin, Plumian professor of astronomy at Cambridge, and a grandson of his renowned namesake, the author of The Origin of Species. His mother was an American lady (maiden name, Maud du Puy) and his sister, the late Mrs. Gwen Raverat, has given an enchanting account of the Cambridge in which he grew up in Period Piece. His godparents, Lord Kelvin and Sir Francis Galton, could scarcely have been more appropriately chosen, considering Darwin's lifelong interest in mathematical physics and eugenies.

Darwin entered Trinity College, Cambridge, in 1906 and was bracketed fourth wrangler in the Mathematical Tripos list of 1909. Immediately after taking Part II of the same Tripos in 1910, he was appointed reader in mathematical physics at the University of Manchester. Seldom can a young physicist have been more fortunate in his first appointment, since Rutherford was his professor, and his colleagues were Niels Bohr and $H$. J. Moseley. Here he worked on the theory of the scattering of $\alpha$-particles, providing a sound theoretical background for Rutherford's experiments which established the nuclear theory of atomic structure. He also gave the first satisfactory theory of X-ray diffraction by crystals, stimulated no doubt by Moseley's brilliant experimental work on X-ray spectra.

During the First World War he was engaged mainly on sound-ranging and flash spotting, being attached to the Royal Engineers as an officer in a field survey unit in France. That this frequently brought him into very dangerous situations was recognized by the award of a Military Cross.

In 1919 he was elected Fellow of, and lecturer in, Christ's College, Cambridge, the College of which his illustrious grandfather had been a momber. Four years later, he was appointed professor of natural philosophy in the University of Edinburgh, where he made outstanding contributions to electromagnetic theory, quantum theory and statistical mechanics. He developed the first general theory of the optical constants of matter in bulk out of the more primitive phenomenon of the scattering of light by atoms, without having to make any assumptions about the structure of the atom. His work with Fowler on the partition of energy in an assembly of atoms or molecules by examining the average state of the assembly, instead of the most probable state, provided a rigorous mathematical foundation for some of the basic concepts in statistical mechanies. He also made important contributions to the theory of the Zeeman effect and of the refractive index of an ionized medium. This work was rocognized by the award of a Royal Medal by the Royal Society in 1935 .

In 1936 he returned to Cambridge as Master of Christ's College, an appointment he relinquished two years later to become the fourth director of the National Physical Laboratory. Within less than a year, the Second World
War had broken out and he had to devote himself to reorganizing the Laboratory to play its part in that conflict. This included methods of dealing with unexploded bombs, and I well remember his helpful co-operation in organizing a scientific test of a dowser who claimed he could locate unexploded bombs which might be buried at depths of 10-15 ft. (To the relief of all the physicists, the dowser was less successful than those who guessed at random.)

In 1941 he was secended to Washington as the first director of the British Central Scientific Office, which he quickly developed into a very efficient organization for maintaining liaison between the scientific war effort of Britain and the United States. In 1942 he returned to Teddington but almost immediately had to divert a considerable fraction of his effort to a simultaneous appointment as scientific adviser to the War Office. Consequently, it was only after the War ended that he could give the National Physical Laboratory his undivided attention.

Considering these distractions, it is very remarkable that three of the present divisions of the National Physical Laboratory were created by Darwin during his period as director. These are the Light Division (1940), the Mathematies Division (1945) and the Autonomics Division (1946), although the last was known in his day as the Control Mechanisms and Electronics Division. In addition to creating new divisions, he was responsible for organizing the withdrawal of the Engineering Division, from which was formed the Hydraulics Research Station at Wallingford in 1947 and the National Engineering Laboratory at East Kilbride in 1949. In the post-War re-organization. of the Department of Scientific and Industrial Research, he took part in the formation of a Radio Research Organization and made arrangements to move the main part of Radio Division to Ditton Park near Slough to form the Radio Research Station, although the final transfor of all the staff involved did not occur until 1957. After his retirement in 1949, he continued to take a close interest in the National Physical Laboratory, serving as a member of its Executive Committee from 1953 until 1959.

Sir Charles was much more than a distinguished physicist and an able administrator. His principal other interests were in education and eugenics. He was a member of the University Grants Committee during 194353 and president of the Eugenics Society from 1953 until 1959. He was deeply concerned over the Malthusian problem and gave an excellent modern analysis of it in his Rede Lecture to the University of Cambridge on "The Problems of World Population". His genial manner and rather roguish sense of humour, combined with his great common sense and originality of approach, made him much sought after when a committeo was being formed to consider some new problem of national importance. It is characteristic of his breadth of outlook that he spent the first two years after his retirement in writing a book on The Next Million Years. He considered that anything less than a million years was too short a period for the kind of changes to occur in which he was interested.

Among the many honours he received were doctorates from the Universities of Bristol, Delhi, Edinburgh, St. 
Andrews, Manchester and Chicago. He was a vice-president of the Royal Society in 1939 and president of the Physical Society of London during 1941-44. He was created a Knight Commander of the British Empire in 1942.

G. B. B. M. Sutherlano

\section{Prof. B. C. P. Jansen}

Barend Coenraad Petrus Jansen was born on April 1, 1884, in the old Dutch town of Zwolle. At the age of twenty he entered the University of Amsterdam as a student of chemistry. He passed his final examination in 1909 and in the same year became assistant to the newly appointed professor of physiology in that University, G. van Rijnberk. In the stimulating scientific atmosphere, created by the young professor in the centuriesold building-in which the Physiological Laboratory is still housed to-day-Jansen took his first steps in biochemistry. The subjects he investigated were mainly related to digestion in the intestinal tract and the metabolism of the amino-acids. Outstanding was his discevery of the synthesis of urea from amino-acids in the mammalian liver in vitro, published in 1915. But before this work had been performed, namely, on July 10, 1912, Jansen had already obtained the doctorate of chemistry of the University of Utrecht, while in 1913 he had been admitted as privaat-docent in Physiological Chemistry at the University of Amsterdam.

Jansen's first period at this University came to an end in 1917, when he moved to Batavia (now Djakarta) in Java, then the capital of the Dutch East Indies. Here he was soon appointed head of the Department of Pharmacy and Chemistry of the Medical Laboratory, the institute in which the epoch-making researches of C. Eijkman and G. Grijns on polyneuritis gallinarum and human beriberi had been performed. The new building erected for this department according to Jansen's design was to be a model for well-equipped research institutions in the tropics.

In $1927 \mathrm{Jansen}$ was also appointed professor of chemistry in the newly founded Medical School in Batavia. But in this year his sojourn in the tropics was already running to its close. For in 1928 he was to return home as professor of physiological chemistry in the University of Amsterdam.

Human nutrition in the tropics, the field of research Jansen entered on his arrival in Java, suited his natural disposition extremely well : he was always most pleased if his results appeared applicable for the immediate benefit of mankind. Indeed his achievements, such as those on the iodine content of potable water in various regions or on the nutritional value of vegetable proteins, were of the highest importance for the health of the indigenous population. But also his greatest achievement of general scientific importance, which gave him world-wide fame, the isolation of pure crystalline vitamin $\mathrm{B}_{1}$ from huge amounts of rice-polishings, was initiated by his wish to provide an easily applicable weapon in the fight against beriberi.

In the autumn of 1928 Jansen returned to his old environments, the Physiological Laboratory in Amsterdam. After some extension and alteration the building provided sufficient room for provisionally accommodating a laboratory for physiological chemistry as well. The execution of plans for a new building was prevented first by the economic depression of the 'thirties, then by the outbreak of the Second World War. But, nevertheless, Jansen's laboratory soon became a centre of nutrition research in the Netherlands, the more so after he had also become director of the Nederlands Instituut voor Volksvoeding (Netherlands Institute for the Nutrition of the People) which was thereupon incorporated in his laboratory.

His devotion to the improvement of human nutrition was one of the chief causes of the rapid diffusion of the modern views on nutrition among the Dutch people. Under his direction many young physicians and chemists were trained in nutrition research; his lectures for the students of medicine generated numerous propagandists for better nutritional habits. Thus for many years he was the leading man in the field of nutrition in his country and one of the prominent specialists in the world. He was decorated by the Queen, he was a member of the Royal Netherlands Academy of Sciences and doctor honoris causa of the Sorbonne in Paris.

In his happy family life Jansen found a full understanding of the significance of his work; two of his three children (one daughter and two sons) worked for their theses under their father's guidance and received their doctor's certificate from his hands.

In 1954 Jansen reached the age of seventy, which obliged him to resign as professor. This did not mean that his activities suddenly came to an end, But gradually his health declined and he died on October 18, 1962, in his seventy-ninth year. His numerous friends, colleagues and pupils will always remember him as one of the noblest men they have ever met.

\section{H. G. K. WEStentrink}

\section{Dr. K. W. Luckhurst}

Kenneth Wilifam Luckhurst, who died on September 19, aged fifty-eight, was for twenty-five years secretary of the Royal Society of Arts and of the Faculty of Royal Designers for Industry. He was educated at the City of London School, and at Cambridge, where he read classics as a scholar of Emmanuel College. The early part of his career was spent in teaching, first at King's School, Canterbury, and then at the University of Edinburgh, where he was lecturer in Greek. In 1935 he was appointed assistant secretary of the Royal Society of Arts, and became secretary two years later. During the Second World War he served in the (Royal) Army Education Corps.

From the beginning of his secretaryship it was apparent that Luckhurst's own wide interests and clear, orderly mind were well suited to the varied and predominantly practical work of the Society for the Encouragement of Arts, Manufactures and Commerce. Holding its traditions in the highest regard, he also recognized how much of its strength derived from adaptability and a continuing sense of usefulness in the existing world. This understanding, and a gift for lucid exposition, informed his major published work, the History of the Society, written in collaboration with Derek Hudson to mark its bicentenary in 1954. Luckhurst afterwards expanded the earlier portion of his contributions into a doctorial thesis, which provides a valuable source of reference for the pioneering experiments in agriculture and chemistry fostered by the Society of Arts. Valuable in another connexion were his Cantor Lectures on the Great Exhibition of 1851, given in the year of the Festival of Britain, and his book The Story of Exhibitions, in which again he demonstrated the force of the Society's example.

The war years apart, the period of Luckhurst's administration was notably beneficial for the Society: membership and revenues more than doubled, additional premises were acquired, its activities, especially those on behalf of industrial design and commercial oducation, were given fresh impetus, and its reputation as a disinterested source of knowledge enhanced. In this last regard much depended on Luckhurst's judgment in organizing, each year, a lecture programme both representative of important developments in the sciences and useful arts, and providing interest and enjoyment for widely different audiences. Judicious attention to the details of each meeting enabled a long succession of visiting speakers to give of their best. $\mathrm{He}$ himself, pleasant and unhurried whatever his preoceupations, was 